\title{
The Effect of Financial Liberalization on Economic Growth in Selected Middle East, North Africa and Sub-Sahara Africa Countries 1986-2018
}

Dr. AbdelrahmanTahir Hag Adam*

Assistant Professor, PhD holder in Economics Sciences (Dean: of the Economics, Banking and Financial Studies program) at: Almadain College for Medical Sciences \& Technology (ACMST)

$\begin{array}{ll}\begin{array}{c}\text { Article History } \\ \text { Received: } 24.08 .2020\end{array} & \begin{array}{l}\text { Abstract: The study investigated the effect of financial liberalization on economic } \\ \text { growth in selected Middle East/North Africa (MENA) countries and Sub-Sahara Africa } \\ \text { Accepted: } 09.09 .2020\end{array} \\ \text { Published: } 30.092020 & \begin{array}{l}\text { countries using data obtained mainly from the World Bank data catalog. The panel unit } \\ \text { root test developed by Im, Pesaran and Shin (IPS) was used to explore the stochastic } \\ \text { properties of the data before estimating the models using Pooled Mean } \\ \text { Group/Autoregressive Distributed Lag estimation procedure for dynamic panel analysis } \\ \text { and found that financial liberalization has had positive and significant influence on } \\ \text { economic growth in MENA countries while financial liberalization had a positive but not } \\ \text { significant influence on economic growth in SSA countries. Thus, the study recommends } \\ \text { the pursuit of rational financial liberalization policies in the MENA countries and SSA } \\ \text { countries as well as encouraging policies of financial inclusion in both sub-regions so as } \\ \text { to continually enjoy the beneficial effect of financial liberalization in their economies. } \\ \text { Keywords: Liberalization, MENA countries, SSA countries, Economy, World Bank. }\end{array} \\ \begin{array}{l}\text { Quick Response Code } \\ \text { Copyright @ 2020: This is an open-access article distributed under the terms of the Creative Commons Attribution license which permits unrestricted }\end{array} \\ \text { use, distribution, and reproduction in any medium for non-commercial use (Non-Commercial or CC-BY-NC) provided the original author and source } \\ \text { are credited. }\end{array}$

\section{INTRODUCTION}

Developing countries are capital deficient countries and the financial system of these countries are expected to among others, mobilize saving and channel same to investors efficiently. The financial system of these countries must be supported with the relevant policies to perform this task and one of such policies is financial liberalization. Financial liberalization refers to measures directed at diluting or dismantling regulatory control over the institutional structures, instrument and activities of agents of different segments of the financial sector. These measures can relate to internal or external regulations (Chandrasekhar, 2004). Simply, financial liberalization entails the removal of restrictions in the financial system. It is believed by some scholars that the introduction of financial liberalization policies will bring about the desired connection between the financial system and economic growth but this has not been sustained in reality. Major international agencies such as World Bank and International Monetary Fund advocated for economic reforms which include liberalization of financial sector by those economies whose financial sector were repressed to augment higher saving, investment and rapid economic growth.

Several developing countries implemented financial liberalization policies under different financial structures and macroeconomic conditions that led to different outcomes. Key objectives of the reform in most developing countries were to reduce direct government intervention and strengthen the role of market forces in the allocation of financial resources, improve the capacity of financial institutions to mobilize domestic savings, enhance effectiveness of monetary policy instruments, promote competition among banks and strengthen their financial soundness (IMF, 1997).

Prior to the introduction of financial liberalization policies, most financial systems in African countries were characterized with government administered interest rate, heavy government presence, strong regulation, pegging of domestic currencies against foreign currencies and restriction on capital movements. These measures according to proponents of financial liberalization fostered distortions and inefficiencies resulting to low saving mobilization, low investment and over-valuation of the domestic currency that affected their economy adversely. Financial liberalization policies were meant to remove all these characteristics in the financial system. There are arguments for and against the financial liberalization and economic growth debate. Some studies found evidence supporting Mckinnon and Shaw hypothesis while other studies found evidence that could not 
support Mckinnon and Shaw hypothesis. Thus, there is no consensus on the effect of financial liberalization on economic growth. The need to explore further the nexus between financial liberalization and economic growth is justified by the conflicting findings as observed in the literature and this study intend to contribute to existing body of knowledge by examining the financial liberalization and growth nexus among selected Middle East/North African (MENA) countries and Sub-Saharan African (SSA) countries.

The rest of the study is subdivided into literature review; method of study; results and discussion; and conclusion and recommendations.

\section{LITERATURE REVIEW \\ Review of Theoretical Literature}

McKinnon (1973) and Shaw (1973) demonstrated that financial repression in developing countries results to high consumption, low savings, low investment, and repressed economic growth. Thus, financial repression causes distortion in the market (Savanhu et al., 2011). The relaxation of financial repression policies in favour of financial liberalization according to Mckinnon and Shaw will lead to reliance on the market allocating mechanism (market forces) which will increase real interest rate that will lead increase in savings, spur investment and ultimately bring about economic growth in developing countries.

Financial repression is synonymous with interest rate pegging, credit ceilings and control, among others. The removal of these would enhance economic growth by allowing for greater efficiency in capital accumulation and allocation as argued the MckinnonShaw framework. According to Rehman and Gill (2013), the important point of McKinnon's hypothesis is that an increase in the desired rate of capital accumulation (private savings) at any given level of income leads to an increase in the average ratio of $\mathrm{M} / \mathrm{P}$ to income implying that a rise in return on capital leads to an increase in the need of real cash balancing holding for accumulation purpose. Thus, money is not a competing asset; rather money is conduit through which accumulation takes place in developing countries. This implies that an increase in real return on money can sharply raise investment saving propensities in developing countries. Shaw (1973), proposed the "debtintermediation hypothesis" whereby increased financial intermediation between savers and investors resulting from financial liberalization and financial development increases the incentive to save and invest, stimulates investment due to increased supply of credit and increased level of average efficiency of investment. For Shaw, the investment (I) is a decreasing function of real interest rate (r) and the saving is an increasing function of economic growth rate $(\mathrm{g})$ and real interest rate $(\mathrm{r})$. i.e.,

$\mathrm{I}=\mathrm{I}(\mathrm{r})$

$\mathrm{S}=\mathrm{S}(\mathrm{r}, \mathrm{g})$
Where: $\frac{a(I)}{a(r)}<0 ; a(\underline{S)}>0$; and $\quad a(\underline{S})>0$

He further argued that increased financial intermediation provided the impetus for growth more directly. Liberalization would result in an expanded, improved and integrated financial sector that would lead to an increase in the savings rate, an increase in the rate of investment (by facilitating lumpier investment); and a direct enhancement to growth (by improved financialtechnologies).

\section{Review of Empirical Literature}

Jbili, Enders and Treichel (1997) made a preliminary assessment of financial sector reforms in three Maghreb countries namely Algeria, Morocco and Tunisia and concluded that financial reforms have had a far reaching implications in strengthening savings and enhancing the sustainability of growth in the three countries but there is still room for improvement and as such recommended the adoption of accelerated reforms to support increased investment and high growth rates. Cook, Hababou and Roberts (2001) examined the effects of financial liberalization on Tunisian banking industry using Data Envelopment Analysis (DEA) models and panel data covering the period $1992-1997$. The study found that financial deregulation has been beneficial to privately owned banks and because of the cautious and well-timed deregulation process, the financial system in Tunisia remained relatively stable despite the turmoil arising from the Asian crisis that crippled many emerging economies of the world.

Galindo, Micco and Ordonez (2002) attempted an inter-sectorial analysis aimed at exploring the financial liberalization and growth nexus in twenty seven (27) countries including developed and developing countries and specifically testing whether economic sectors that rely on external financing grow faster than others after financial liberalization. The study found that financial liberalization promotes financial development and by extension, stimulating growth of the legal framework (rules and institutions) that support creditor rights are in place.

Achy (2003) in an attempt to explore the financial liberalization and economic growth nexus for the period 1979- 1998 across selected Middle East North African (MENA) countries using an economic growth model with real GDP, a set of financial depth indicators, real interest rate, private investment -rate, external debt/GDP ratio among others. The study found that financial liberalization has distorted credit allocation by the financial markets in favour of consumption as against productive activities.

Fowowe (2004) using cross-country analysis examined the financial liberalization and growth nexus for 19 sub-saharan African countries for the period 1978 - 2000. Adopting financial liberalization indexes 
and dummy for pre - liberalization and post liberalization as well as other control variables such as income per capital, investment, life expectancy, degree of openness and debt service ratio found evidence in support of McKinnon - Shaw hypothesis that financial liberalization enhances economic growth.

Ozdemir and Erbril (2008) investigated the nexus of financial liberalization and economic growth for 10 European countries and Turkey for the period 1995 - 2007 using proxies of financial liberalization indexes such as foreign direct investment, other investments, portfolio investments, trade openness indexes and other control variables. They found supporting evidence to the long - run growth path as anticipated by the new growth theorists.Thus, they recognized financial liberalization as an important policy tool in stimulating economic growth.

Mwanaga and Sanday (2013) investigated the effect of financial sector liberalization on economic growth of Uganda. The study used annual time series data on gross domestic product (GDP), lending rate, real exchange rate, inflation rate, ratio of money supply to gross domestic product and ratio of private sector credit to gross domestic product. These data were analysed using the Vector Auto Regression (VAR) and error correction models. The results indicate a long run relationship between the represent and independent variables in general and in particular that financial liberalization has a positive impact on economic growth in Uganda.

Ullah and Hashmi used eight dimensions of banking sector reforms to capture financial liberalization for 58 countries comprising 28 developed and 30 less developed countries and applying panel unit root and co-integration tests. The study found a positive and more significant relationship between financial liberalization and economic growth in less developed countries relative to developed countries which the study claimed was attributed to the dominance of banking activities in the financial system of less developed countries as against the dominance of capital market activities in developed counties. The study also found that too much of financial liberalization is harmful to developed countries and beneficial to less developed countries as they are yet to reach their threshold, thus having the capacity to absorb the beneficial effects of more financial reforms which are in fact, beneficial to the development of financial intermediaries and hence economic growth.

Akinsola and Odhiambo (2017) investigated the impact of financial liberalization on economic growth in 30 sub-saharan African countries for the period 1980 - 2015; classifying countries into low and middle income and using Generalized Method of Moments (GMM) in estimating a dynamic panel method in line with Arellano - Bond approach. The study found that overall, financial liberalization is positively related to economic growth but when income differentials across sub-saharan African countries is considered, financial liberalization had a beneficial effect on growth of middle income countries and a harmful effect on growth of low income countries and the study recommended that financial liberalization policies should be implemented with caution, that is, sequencing and timing of such policies should be taken seriously so as to avoid endangering financial stability.

No study has compared the outcome of financial liberalization on economic growth between MENA and SSA countries from the empirical literature reviewed. What we found present in the existing literature were studies concentrating either on SSA countries or MENA countries and they are associated with mixed conclusions. This study intend contributing to the existing body of literature by exploring the liberalization-growth nexus across selectedcountries in MENA and SSA region.

\section{Method OF STUdy}

The variables that are pertinent to MckinnonShaw arguments are interest rate, saving, investment and economic growth. But De Gregorio and Guidotti (1993) expressed that real interest rate is not an adequate indicator to proxy financial repression and suggested the use of private sector credit to GDP. Bumann, Hermes and Lensink (2012) attributed the lack of consensus in studies of financial liberalization and economic growth to lack of homogeneous measure of financial liberalization index. Some studies adopted capital account liberalization while others adopted equity market liberalization and at some point others adopted banking sector liberalization. In line with the above reasoning, a financial liberalization index that cut across seven financial sector reforms that cuts across the capital account, equity market and banking sector developed by Abiad, Detragiache, and Tressel (2008) were extended and used.

Following the above narrative, the effect of financial liberalization on economic growth is stated as follows:

$g d p p \quad=\quad f \quad($ flib $, \quad r s v, \quad$ gexp, $\quad$ docr $)$
$\ldots \ldots \ldots \ldots \ldots \ldots \ldots \ldots \ldots \ldots \ldots \ldots \ldots \ldots \ldots \ldots \ldots$
(2)

Where:

$g d p p c=$ gross domestic product per capita growth rate and it is used as proxy for economic growth

flip = financial liberalization index

reserve $=$ ratio of external reserve to short term debt

gexp = ratio of government expenditure to gross domestic product

docr $=$ ratio of domestic credit to the private sector to gross domestic product. 
Equation (1) is the functional form of the model and is the exact form but economic relationships are inexact therefore

Equation (2) incorporates the stochastic term, u. Apriori expectations are: $1, \beta 2, \beta 3 \& \beta 4>0$.

\section{The data for this study was sourced from the World Bank data catalog from internet and journals.}

The study employed descriptive and quantitative analysis. The descriptive analysis comprises measures of central tendencies, dispersion, skewness, kurtosis and graphs were used to analyse drifts in the data. The behavior of the dataset using the descriptive analysis determined the appropriate method adopted for the study. We suspected that the dataset are not mean-reversing, a formal unit root test was conducted using Im, Pesaran and Shin (IPS) panel unit root test and a Pooled Mean Group (PMG)/ Autoregressive Distributed Lag (ARDL) estimation method to explore the long run relationship among the variables. The adoption of the IPS panel unit root test was informed by its ability to allow the persistence parameter (autogressive coefficient) to vary across each country. Put differently, given the structural differences and changes among the countries included in this study, it would be wrong to assume a common unit root process across these countries.

\section{RESUlTS AND DiSCUSSION}

Table 1:- Descriptive Statistics for Middle East/North African (MENA) Countries

\begin{tabular}{llllll}
\hline & GDPGR & FLIB & GEXP & RESERV & DOCR \\
\hline Mean & 2.221032 & 0.526507 & 26.79777 & 283.1900 & 34.29278 \\
Median & 2.202440 & 0.595238 & 27.15509 & 35.25648 & 29.76037 \\
Maximum & 122.9683 & 0.904762 & 35.46345 & 3840.120 & 71.54544 \\
Minimum & -62.22509 & 0.035714 & 12.96168 & 2.714111 & 3.904611 \\
Std. Dev. & 13.02501 & 0.246750 & 4.804420 & 789.0628 & 20.88258 \\
Skewness & 5.296748 & -0.454087 & -0.405416 & 3.213614 & 0.175759 \\
Kurtosis & 63.61206 & 2.029115 & 3.202787 & 12.21297 & 1.595642 \\
Jarque-Bera & 20192.23 & 9.426125 & 3.725708 & 673.0033 & 11.17752 \\
Probability & 0.000000 & 0.008977 & 0.155229 & 0.000000 & 0.003740 \\
Sum & 284.2921 & 67.39286 & 3430.114 & 36248.33 & 4389.476 \\
Sum Sq. Dev. & 21545.67 & 7.732488 & 2931.472 & 79072746 & 55382.43 \\
Observations & 128 & 128 & 128 & 128 & 128 \\
\hline
\end{tabular}

Source: Author's Computation

Table 1 above shows the descriptive statistics of variables in the regression model of Middle East/North African Countries. From the table, there are 128 observations. During the period under review gross domestic product per capita growth rate (GDPGR) across the MENA countries had a minimum of- 62. The maximum value of this variable was 122.9 while the mean and median of gross domestic product per capita growth rate (GDPGR) across the MENA countries are 2.2210 and 2.2024 respectively. Also, during the period under investigation, the mean of financial liberalization index across the MENA countries reached the minimum of 0.035714 ; while it achieved the maximum value of 0.904762 . The financial liberalization index averaged 0.526507 during the period under review. Government expenditure in the MENA countries averaged 26.79777per. The highest value during the period was 35.46345 ; while the minimum value was 12.96168 . Reserves (RESERV) in the across the MENA countries had an average of 3840.120. The maximum and minimum values of the reserves were 3840.120 and 2.714111 respectively. The maximum and minimum values of the domestic credit (DOCR) in the MENA countries were 71.54544 and 3.904611 respectively. The mean value of the domestic credit was 34.29278.
The Skewness values for all the variables are greater than 0.00. Financial liberalization index, (FLIB) and government expenditure, domestic credit (DOCR), and government expenditure (GEXP) have skewness value of that are close to zero. They are not much different from zero. Their distributions can be taken as normal. Reserves and gross domestic product growth rate have skewness value greater than 0.00 . This implies that the distributions of the variables are positively skewed. The Kurtosis values for RESERV, GDPGR and GEXP are greater than 3.000. Thus, they have excess kurtosis and are leptokurtic, that is, their distributions have tops that are more pointed than the normal distribution. The kurtosis value for financial liberalization index and domestic credit (DOCR) are less than 3.00. This means that their distribution have flatter top than the normal distribution. It is platykurtic. The Jacque-Bera (JB) test of normality for the variables shows that the distributions of the GDPGR, FLIB, RESERV, DOCR, are not normal. The P-values of the JB statistics for these variables are less than the critical 0.05 . The distribution of government expenditure (GEXP) is normal. 
Table 2:- Descriptive Statistics for Sub-Sahara African (SSA) Countries

\begin{tabular}{llllll}
\hline & GDPGR & FLIB & GEXP & RESERV & DOCR \\
\hline Mean & 2.328736 & 0.634580 & 26.30246 & 248.4043 & 26.61783 \\
Median & 1.925124 & 0.630952 & 27.89980 & 34.18028 & 14.84541 \\
Maximum & 30.35658 & 0.952381 & 38.60811 & 2302.442 & 78.29413 \\
Minimum & -9.216298 & 0.000000 & 9.615626 & 3.149426 & 3.139281 \\
Std. Dev. & 4.165067 & 0.240838 & 6.448772 & 447.7937 & 22.45260 \\
Skewness & 2.600938 & -0.432834 & -0.759411 & 2.620847 & 1.004990 \\
Kurtosis & 18.53769 & 2.237586 & 3.028114 & 10.15431 & 2.477459 \\
Jarque-Bera & 1431.890 & 7.096832 & 12.30724 & 419.5172 & 23.00305 \\
Probability & 0.000000 & 0.028770 & 0.002126 & 0.000000 & 0.000010 \\
Sum & 298.0782 & 81.22619 & 3366.715 & 31795.75 & 3407.082 \\
Sum Sq. Dev. & 2203.168 & 7.366372 & 5281.506 & 25465937 & 64023.15 \\
Observations & 128 & 128 & 128 & 128 & 128 \\
\hline
\end{tabular}

Source: Author's Computation

Table 2 above shows the descriptive statistics of variables in the regression model for Sub-Sahara African (SSA) Countries. From the table, there are 128 observations. During the period under review gross domestic product per capita growth rate (GDPGR) across the SSA countries had a minimum of -9.216298 . The maximum value of this variable was 30.35658 ; while the mean and median of gross domestic product per capita growth rate (GDPGR) across the SSA countries are 2.328736 and 1.925124 respectively. Also, during the period under investigation, the mean of financial liberalization index across the countries reached the minimum of 0.000000 ; while it achieved the maximum value of 0.952381 . The financial liberalization index averaged 0.634580 during the period under review. In the 128 quarters, government expenditure in the SSA countries averaged 26.30246 quarter. The highest value during the period was 38.60811; while the minimum value per quarter was 9.615626. Reserves (RESERV) in the across the SSA countries had an average of 248.4043. The maximum and minimum values of the reserves were 2302.442 and 3.149426 respectively. The maximum and minimum values of the domestic credit (DOCR) in SSA countries were 78.29413 and 3.139281 respectively. The mean value of the domestic credit was 26.61783 .

The Skewness values for all the variables are greater than 0.00. Financial liberalization index, (FLIB) and government expenditure (GEXP) have skewness close to zero. They are not much different from zero. Their distributions can be taken as normal. Reserves (RESERV) and gross domestic product growth rate (GDPGR) have skewness value greater than 0.00. This implies that the distributions of the variables are positively skewed. The Kurtosis values for RESERV, GDPGR, and FLIB are greater than 3.000. Thus, they have excess kurtosis and are leptokurtic, that is, their distributions have tops that are more pointed than the normal distribution. The kurtosis values for financial liberalization index and government expenditure (GEXP) are less than 3.00. This means that their distribution have flatter top than the normal distribution. It is platykurtic. The Jacque-Bera (JB) test of normality for all the variables shows that the distributions of the variables are not normal. The P-values of the JB statistics for these variables are less than the critical 0.05 .

Table 3:- IPS Panel Unit Root Test Results

\begin{tabular}{lllll}
\hline \multirow{2}{*}{ Variables } & \multicolumn{2}{c}{ MENA Countries } & \multicolumn{2}{c}{ SSA Countries } \\
\cline { 2 - 5 } & LEVEL & 1 $^{\text {st DIFFERENCE }}$ & LEVEL & $1^{\text {ST }}$ DIFFERENCE \\
\hline GDPGR & $-5.66^{* * * *}$ & -- & $-3.15^{* * * *}$ & -- \\
FLIB & 0.38 & $-4.43 * * *$ & 0.24 & $-6.83^{* * *}$ \\
GEXP & -0.84 & $-5.56^{* * *}$ & -0.01 & $-7.82^{* * *}$ \\
RESERV & -0.54 & $-1.79 * *$ & -0.46 & $-7.60^{* *}$ \\
DOCR & -0.09 & $-3.66^{* * *}$ & 0.13 & $-8.85 * * *$ \\
\hline
\end{tabular}

Source: Author's Computation

$* * * \& * *$ indicate significance at $1 \%$ and $5 \%$ respectively.

Table 3 show the panel unit root result based on classification by region, Gross Domestic Product Per Capita growth rate (GDPGR) was stationary at level for Middle East/North Africa (MENA) countries as well as Sub-Saharan African (SSA) countries given the test statistic of -5.66 and -3.15 and their associated probability that is less than $1 \%$ significance level. Other variables such Financial Liberalization Index (FLIB), Government Expenditure (\% of GDP), External Reserve (RESERV) were not stationary at level for both regions. However, they became stationary at fist difference. Thus, all variable except (GDPGR) are integrated at order one. 


\begin{tabular}{|c|c|c|}
\hline \multirow[t]{2}{*}{ Variable } & MENA Countries & SSA Countries \\
\hline & Coefficient & Coefficient \\
\hline \multicolumn{3}{|c|}{ Long Run Equation } \\
\hline DOCR & -0.01 & -0.07 \\
\hline FLIB & $2.50 * * *$ & 4.43 \\
\hline RESERV & 0.00 & 0.00 \\
\hline GEXP & $-0.20 * * *$ & 0.07 \\
\hline \multicolumn{3}{|c|}{ Short Run Equation } \\
\hline COINTEQ01 & $-1.25 * * *$ & $-0.68 * * *$ \\
\hline$\Delta(\mathrm{DOCR})$ & -0.71 & -0.19 \\
\hline$\Delta($ FLIB $)$ & 17.51 & -6.42 \\
\hline$\Delta(\mathrm{RESERV})$ & -0.00 & -0.01 \\
\hline$\Delta(\mathrm{GEXP})$ & $-0.57 * * *$ & -0.20 \\
\hline $\mathrm{C}$ & $8.60 * * *$ & -0.50 \\
\hline
\end{tabular}

Source: Author's Computation

$* * * \& * *$ indicate significance at $1 \%$ and $5 \%$ respectively.

Table 4 above shows the long and short run results for Middle East / North African (MENA) and Sub - Sahara African (SSA) countries. In the long run, the coefficient of financial liberalization index is 2.50 for MENA countries suggesting a positive relationship between financial liberalization and Economic growth and this coefficient is significant given its associated probability value at $1 \%$ significance level. Its counterpart of Sub-Sahara African (SSA) countries is 4.43 suggesting a positive relationship with economic growth. However, the coefficient is not significant given the reported probability value of 0.20 which is greater than 0.05 critical values. The coefficient of Credit to Private Sector (\% of GDP) for MENA countries of -0.01 show that credit by banks is negatively related to economic growth and the coefficient for SSA countries is -0.07 . These coefficients are not significant given their reported probability values of 0.33 for MENA countries and 0.48 for SSA countries at 5\% significance level. The coefficient for Foreign Reserve (RESERV) for MENA and SSA countries are 0.00 . These coefficients are not significant given their reported probability values of 0.22 and 0.68 at $5 \%$ significance level. The coefficient for Government Expenditure (\% of GDP) (GEXP) for
MENA countries was -0.20 . This coefficient is significance at $1 \%$ significance level. Its counterpart for SSA countries is 0.07 and it is not significant. In the short run equation, the co-integrating equation coefficient (COINTEQ01) of -1.25 and -0.68 are rightly signed and significant at $1 \%$ significance level given their respective probability values suggesting long run relationship between the variables. The coefficient of financial liberalization index for MENA and SSA countries are 17.51 and 6.52 respectively however these coefficients are not significant. The coefficient for Credit to Private (\% of GDP) of -0.71 and -0.19 for MENA and SSA countries show an inverse relationship in the short run. These coefficients are however not significant at 5\% significance level. The coefficients of Foreign Reserve show an inverse relationship with Economic growth but these coefficients are not significant for MENA and SSA countries. The coefficient of government expenditure(GEXP) for MENA and SSA countries are -0.57 and -0.20 suggesting an inverse relationship with Gross Domestic Product Per Capita Growth Rate (GDPGR) and the coefficients are significant at $1 \%$ and $5 \%$ significance level.

Table 5:- Short Run Coefficients for Sub-Saharan African (SSA) Countries

\begin{tabular}{lllll}
\hline Variable & Botswana & Ghana & Nigeria & South Africa \\
\hline Cointeq01 & $-0.77^{*}$ & $-0.72^{*}$ & $-0.84^{*}$ & $-0.39^{*}$ \\
$\Delta$ FLIB & 19.18 & -5.77 & 9.83 & 2.45 \\
$\Delta$ GEXP & $-0.25^{* * *}$ & $-0.08^{* *}$ & -0.06 & $-0.41^{*}$ \\
$\Delta$ RESERV & $0.00^{*}$ & $-0.05^{*}$ & $0.00^{*}$ & $-0.01^{* *}$ \\
$\Delta$ DOCR & -0.46 & $-0.35^{* *}$ & 0.04 & 0.01 \\
\hline
\end{tabular}

Source: Author's Computation

$*, * * \& * * *$ indicate $1 \%, 5 \%$ \& $10 \%$ significance level respectively.

Table 5 above shows the short run result for countries of Sub-Sahara Africa (SSA). Firstly, it can be seen that the cointegrating equation coefficient satisfy the conventional condition of been negative and less than one and is significant at $1 \%$ significance level. Specifically, the coefficient for cointegrating equation for Botswana is -0.77 suggesting that disturbances to equilibrium in the finance liberalization - growth model is reconciled annually at a speed of about $77 \%$ in Botswana. Ghana also had a speed of adjustment of about $72 \%$. Nigeria had the highest speed of adjustment across these four countries with a speed of about $84 \%$ 
and South Africa had the lowest of about 39\%. This suggests that distortions in the system are gradually eliminated when they arise. The short run coefficient for financial liberalization index for all four countries appeared with a positive sign except for Ghana. Botswana's coefficient was 19.18; that of Nigeria was 9.83; 2.45 for South Africa and -5.77 for Ghana. Interestingly all these coefficients are not significant. Thus, the effect of financial liberalization on economic growth is said to be uniform in the region. The short run coefficients for government expenditure appeared with negative signs for all four countries. However, the significance level varied as the coefficient for Botswana was significant at $10 \%$ while that of Ghana was significant at $5 \%$, South Africa $1 \%$ and coefficient for
Nigeria is not significant. This negates our appriori expectation of positive relationship between Government expenditure and economic growth. The coefficient for foreign reserve appeared with a positive sign for Botswana and Nigeria whereas that of Ghana and South Africa appeared negative. The coefficients for all four countries are significant. The coefficient for domestic credit to private sector shows that the variables is irreversibly related to economic growth for Botswana and Ghana and positively related to growth in Nigeria and South Africa. The significance of the coefficient could not be established for three out of the four countries. Only Ghana's coefficient was significant.

Table 6:- Short Run Coefficients for Middle East/North Africa (MENA) Countries

\begin{tabular}{lllll}
\hline Variable & Algeria & Libya & Morocco & Tunisia \\
\hline Cointeq01 & $-0.82 *$ & $-1.31 *$ & $-1.62^{*}$ & $-1.24 *$ \\
$\Delta$ FLIB & -7.27 & 110.15 & -23.80 & -9.00 \\
$\Delta$ GEXP & $-0.07 * *$ & -1.01 & $-0.56 * *$ & $-0.63 *$ \\
$\Delta$ RESERV & $-0.00 * * *$ & 0.01 & $-0.04 *$ & $0.01 * * *$ \\
$\Delta$ DOCR & $-0.02 * * *$ & $-2.60 * *$ & -0.03 & $-0.20 *$ \\
\hline
\end{tabular}

Source: Author's Computation

$*$, ** \& *** indicate $1 \%, 5 \% \& 10 \%$ significance level respectively.

Table 6 above shows the short run result for middle East/North Africa countries. Specifically, the coefficient for cointegrating equation appeared with its theoretically expected negative sign. However, the magnitudes of these coefficients for all four countries are greater than unity except Algeria. This suggests that only Algeria restores long run stable relationship in this class of countries in line with the conventional conditions. The coefficient for financial liberalization showed up with negative signs for Algeria, Morocco and Tunisia while that of Libya showed positive. However, these coefficients are not significant. Thus, the coefficients are jointly not different from zero and by implication suggesting uniformity on the effect of financial liberalization on economic growth. The coefficient for government expenditure appeared with negative sign for all four countries suggesting an inverse relationship between government expenditure and economic growth for Middle East /North African Countries in the short run. The magnitude of the coefficient for all four countries was less than unity except for Libya. Similarly, all four countries except Libya were significant. Algeria and Morocco were significant at 5\% significance level while Tunisia was significant at $1 \%$ significance level. The coefficient of external reserve appeared with its theoretical expected positive sign for Libya and Tunisia while those of Algeria and Morocco appeared with negative sign. In terms of significance, all four countries except Libya were significant. By magnitude, the coefficient for all countries remained less than unity. The coefficients for domestic credit to private sector appeared negative for all four countries and were less than unity except the coefficient for Libya that recorded about 2.60. All coefficients for domestic credit to private sector are significant except for Morocco that was not significant.

\section{CONCLUSIONS AND RECOMMENDATION}

Financial liberalization policies have had positive and significant effect on economic growth for Middle East/North African (MENA) countries as suggested by the coefficient. It shows that increase in financial liberalization of a unit would bring about 2.5 unit increase output growth this result is truly fascinating for MENA countries. On the other hand, financial liberalization policies have had positive and not significant effect on economic growth for SubSahara African (SSA) countries. This finding is line with Achy (2003) for MENA countries while the findings for Sub-Saharan African countries contradict the study of Fowowe (2004) that found supportive evidence for Mckinnon (1973) and Shaw (1973) hypotheses. Domestic credit to the private sector is inversely related to output growth for MENA countries as well as SSA countries. The inverse relationship is however not significant in both regions. This suggests that more needs to be done in area of putting down strong institution that would monitor the activities of financial institutions saddled with theresponsibility of issuing credit. Foreign reserve is not significant for countries in both regions (MENA and SSA). Foreign reserve depletion should only be encouraged if and only if it would aid businesses acquire materials and equipment that cannot be sourced locally. Government expenditure is negatively related to output growth for MENA counties while it is positively related to output 
growth for SSA countries but not significant. Government expenditure have been on the increase over the years but this increment should be channelled and managed properly so economic agents (households and businesses) can benefit from it.

Thus, the study recommends the pursuit of rational financial liberalization policies in the Middle East/ North Africa (MENA) countries and Sub-Sahara Africa (SSA) countries as well as encouraging policies of financial inclusion in both sub-regions so as to continually enjoy the beneficial effect of financial liberalization in their economies.

\section{REFERENCES}

1. Abiad, A., Detragiache, E., \& Tressel, T. (2008). A new database of financial reforms.IMF Working Paper WP/08/266, December 2008

2. Achy, L. (2003). Financial liberalization, saving, investment and growth in MENA countries, Forthcoming in Middle-East Economics, vol. 6.

3. Ajie, H.A. (2011). Fundamentals of Monetary Economics. Port Harcourt: Pearl Publishers.

4. Ajie, H.A., Akekere, J., \& Ewubare, D. (2008). Financial institutions: markets and contemporary issues. Port Harcourt, Pearl Publishers

5. Akinsola, F.A., \& Odhiambo, N.M. (2017). The impact of financial liberalization on economic growth in Sub-Saharan Africa.Cogent Economics\&Financehttps://doi.org/10.1080/ 23322039.2017.1338851

6. Arestis, P., \& Demetriades, P. (1999). Financial liberalization: The experience of developing countries, Eastern Economic Journal, 25: 441-457

7. Asamoah, G.N. (2008). The impact of the financial sector reforms on saving, investment and growth of Gross Domestic Product (GDP) in Ghana. International Business and Economic Research Journal, vol. 7(10), 73-84.

8. Babajide, F. (2011). Financial liberalization policies and economic growth: Panel evidence from sub-saharan Africa. University of Ibadan, pp.1-23.

9. Banam, K.C. (2010). Impact of financial liberalization on economic growth in Iran: An empirical investigation. Middle Eastern Finance and Economics, Issue 7, 6-37.

10. Bandiera, O., Caprio, G., Honohan, P., \& Schiantarelli, F. (2000). Does financial reform raise or reduce saving?. Review of Economics and statistics, 82(2), 239-263.

11. Chandrasekher, C.P. (2004). Financial liberalization and the macroeconomics of poverty reduction. Draft Thematic Summary on Financial Liberalization for the Asia-Pacific Programme on the Macroeconomicsof Poverty Reduction.

12. Cook, W. D., Hababou, M., \& Roberts, G. S. (2001). The effects of financial liberalization on the Tunisian Banking Industry: a non-parametric approach. Topics in Middle Eastern and North African Economies, 3.

13. De Gregorio, J., \& Guidotti, P. (1993). Financial development and economic growth. Washington DC. International Monetary Fund.

14. Demirguc-kunt, A., \& Detriagiache, E. (1998). Financial liberalization and financial fragility.World Bank Working Paper

15. Diaz-Alejandro, C. (1985). Good-bye financial repression, hello financial crash. Journal of Development Economics. 19, Pp. 1 - 24.

16. Faria, J. A., Paula, F., Luiz, P., CC, M., \& Meyer, R. T. (2009). Financial liberalization, economic performance and macroeconomic stability in Brazil: an assessment of the recent period. Anais do $37^{\circ}$ Encontro Nacional de Economia da ANPEC. Foz do Iguaçu: ANPEC.

17. Galindo, A., Micco, A., \& Ordoñez, G. (2002). Financial liberalization and growth: Empirical evidence. Inter-American Development Bank, 1-35.

18. Greenwood, J., \& Jovanovic, B. (1990). financial development, growth and the distribution of income. Journal of Political Economy, 98, pp.1076 $-1107$.

19. Im, K.S., Pesaran, M.H., \& Shim, Y. (1997). Testing for unit root in heterogeneous panels. MS, Department of Applied Economics, University of Cambridge.

20. Jhingan, M.L. (2008). Monetary Economics, Sixth Edition, Delhi: Vrinda Publications Ltd.

21. Johnston, R.B., \& Sandarajan, V. (1999). Sequencing financial sector reforms, country experiences and issues.International Monetary Fund, Washington D.C

22. Kaminsky, G.L., \& Schmukler, S.L. (2003). Shortrun pain, long-run gain: The effects of financial liberalization. International Monetary Fund Working Paper wp/03/34, Washington D.C

23. Kaskende, L., \& Atingi-Ego, M. (2003). Financial liberalization and its implication for the domestic financial system: The case of Uganda. Research paper 128, African economic research consortium, Nairobi.

24. Mahambare, V., \& Balasubramanyam, V.N. (2000). Liberalization and savings in developing countries: The case of India. Department of Economics working papers, Lancaster University.

25. Mckinnon, R. (1973). Money and capital in economic development. Washington, D.C: Brookings Institution

26. McKinnon, R.I. (1991). The Order of economic liberalization: financial control in the transition to a market economy. John Hopkins University Press Baltimore.

27. Munir, R., Awan, R.U., \& Hussain, Z. (2010). Investment, saving interest rate and bank credit to the private sector nexus in Pakistan. International Journal of Marketing Studies, 2(1), 140-146.

28. Mwanga, J., \& Sanday, A. (2013). The effect of financial sector liberalization on economic growth: 
Evidence from Uganda. International Journal of Economics and Management Sciences vol. 2(9), 58-79.

29. Obamuyi, T.M. (2009). Government financial liberalization policy and development of private sector in nigeria: Issues and Challenges. Available at: http://www.growinginclusive markets.org

30. Odhiambo, N.M. (2009). Interest rate liberalization, financial deepening and economic growth in South Africa: Ninth Annual IBER \& TLC Conference Proceedings.

31. Ogaki, M., Ostry, J., \& Reinhart, C.M. (1996). Savings behavior in low and middle income developing countries: A comparison. International Monetary Fund Staff papers 43(1), 38-71.
32. Okereke, E.J. (2009). Money and the Nigerian financial system, 3rd Edition.Owerri, Jeso International

33. Omankhanlen, A.E. (2012). The financial sector reforms and their effect on the nigerian economy. Economy Transdisciplinary Cognition, 15, 45-57.

34. Orji, A., Ogbuabor, J. E., \& Anthony-Orji, O. I. (2015). Financial liberalization and economic growth in Nigeria: An empirical evidence. International Journal of Economics and Financial Issues, 5(3) 663-672.

35. Shaw, E. (1973) Financial deepening in economic development. New York: Oxford University Press.

36. Stiglitz, J. (2000). Capital market liberalization, economic growth and instability. World

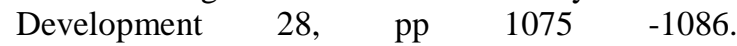

